\title{
Development Ethics - Why? What? How? A formulation of the field
}

\author{
Des Gasper -- International Institute of Social Studies, The Hague (Erasmus University \\ Rotterdam), gasper@iss.nl ${ }^{1}$
}

Prefinal version of a paper that later appeared in J. of Global Ethics, 2012, 8(1), 117-135.

\begin{abstract}
The paper assesses the rationale, contributions, structure, and challenges of the field of development ethics. Processes of social and economic transformation involve great risks and costs and great opportunities for gain, but the benefits, costs and risks are typically hugely unevenly and inequitably distributed, as is participation in specifying what they are and their relative importance. The ethics of development examines the benefits, costs, risks, formulations, participation, and options. The paper outlines a series of ways of characterizing such work, arguments for and against its importance, and some of its important sources and contributions, especially from the interdisciplinary stream of work represented over several decades by Denis Goulet. Definitions are diverse since the work covers many different intersections of practice and theorizing, at multiple levels. The paper considers and replies to arguments against discussing development ethics: claims that it involves only endless proliferation of different opinions, is an expensive luxury that undermines long-run development, is superfluous if one already works with the capability approach or the human rights tradition, or never has influence. Finally, it presents suggestions for how development ethics thinking can have increased impact, with reference to incorporation in policy analysis and planning methods, professional codes and training, and to its intellectual location and communication strategies. The field should articulate the methodological pragmatism which much of it has adopted, consistent with its required role as a practice-oriented interdisciplinary meeting ground.
\end{abstract}

Keywords: practical ethics; human rights; human development; human security; sustainability; methodological pragmatism

\footnotetext{
${ }^{1}$ This paper grows out of: a public lecture at the Universidad de los Andes, Bogota, in 2007; a note in Human Development Insights, 24, http://hdr.undp.org/en/media/HD_Insights_January2009.pdf; ideas in Gasper and St. Clair (2010); and a presentation to a UNESCO conference on 'Rethinking Development: Ethics and Social Inclusion', Mexico City, 2011. My thanks go to an anonymous referee and the journal editor for their advice, and to Asuncion Lera St. Clair for ongoing intellectual partnership and valuable comments on the present paper.
} 


\section{Why essay development ethics?}

Modernity 'promises us adventure, power, joy, growth, transformation of ourselves and the world-and at the same time, ...threatens to destroy everything we have, everything we know, everything we are'

(Berman 1983, 15).

The rationale for the field of development ethics is that processes of social, political and economic development bring both enormous opportunities and enormous threats for humankind, individually and collectively, and that the associated benefits and costs are typically highly unfairly distributed. Ten to fifteen million people a year, for example, are displaced from their place of residence in order to make way for development projects, with often inadequate or no compensation and with severe harm to their well-being. While human powers have grown astonishingly in the past three centuries, so have the differentials of power and good fortune between different persons and groups within countries and between countries and regions. Many countries unfortunately match the description that Denis Goulet (1983) cited for Mexico: a rich country full of poor people.

'Development' - whether understood as fundamental transformations including industrialisation, urbanisation, globalisation and more; as planned intervention; as improvement in human welfare; or as expansion of valued attainable opportunities - is correspondingly a strongly ethically-laden field. What are all the running, risk-taking and intervention for? What are improvement, welfare, the good life? Why are so many of the materially affluent spiritually poor? Who benefits, who loses? Who decides, who is consulted, who is not? Whose values count?

Some key themes in development ethics have been that, first, the gains of some groups have been directly conditional on planned suffering for others-a theme for which we can take Peter Berger's label: 'pyramids of sacrifice' (Berger 1974) —as in the suffering of slaves in the processes of generation of agricultural and mining wealth from the Americas, or of rural labourers displaced to become urban proletarians in the industrialisation of Western Europe and Russia. More generally, long term societal development involves enormous investments by preceding generations that are often to the benefit overwhelmingly of later generations, not of themselves. This investment has been induced in diverse ways besides voluntary contract: through forced labour, physical displacement leading into capitalist wage-labour, or labour perceived in terms of loyalty, duty, honour, solidarity or self-fulfilment.

Mainstream economics often employs the utilitarian principle of maximising net benefits regardless of on whom the benefits or costs fall, sharing Lenin's readiness to 'break eggs in order to make omelettes'. Besides the disputes over that principle comes the question of how it is applied in reality. Michael Cernea, the first and leading sociologist in the history of the World Bank, remarks that: 'we find much in evaluation work that is totally ethically unacceptable' (Cernea 2006), for example studies that legitimated creating parks for rich tourists at the cost of removing the livelihoods of poor local residents, on the basis of projections of future numbers of tourists that were never plausible. We see here the combination of a cost-benefit-analysis methodology that impresses through its apparent inclusiveness, sophistication and precision but that can endorse proposals that 
make poor people poorer for the benefit of richer people, and a practice that exacerbates this feature by its openness to manipulation and to generation of highly unreliable scenarios.

'Some get the gains, others get the pains', remarked Cernea (2006), after a lifetime of observation of forced displacement of low-income populations. The creation of national parks, for example, has typically been comprehensively at the expense of the previous residents. Oliver-Smith records the 'abject failure of so many resettlement projects to produce tangible benefits for displaced communities. .... [T] he record of dismal failures and concomitant pain and suffering for the displaced continues with depressing regularity' (Oliver-Smith 2009, 17). Even where compensation exercises are present: 'Overwhelming evidence documents pervasive and multidimensional distortions of compensation in practice' (Cernea 2008, 56). Thirty-six out of forty-four dam-related resettlement cases reviewed by Scudder (2005) showed direct material loss to the people displaced, quite apart from the psychological and social losses.

Second, good fortune for some can generate unplanned suffering for others, as when booming incomes in some sections of society or some parts of the world pull food resources out of poorer areas and out of the affordable reach of the poorest people, leading even to famine and death. Amartya Sen elaborated how famines are not necessarily caused by lack of food but by poor people's lack of power to command food, which can occur partly as a side-effect of richer people's greater power to command resources (Sen 1981; Dreze and Sen eds. 1990). He analysed these mechanisms in a series of famines that cost millions of lives, in the $19^{\text {th }}$ century in India and Ireland, the Bengal famines of 1943-4 and 1974, and the Ethiopian famines of 1973 and 1974. Mike Davis (2001) builds on Sen's insight in an account of the late $19^{\text {th }}$ and early $20^{\text {th }}$ century famines in India, China and Brazil which brought tens of millions of deaths. He recounts how the impacts of climatic shocks caused by el Niño currents in the Pacific Ocean were mediated by new systems of colonial power, global trade connections and economic ideology. Comparable shocks in the $18^{\text {th }}$ century in China and India had been managed with far less loss of life, by governments that were not committed to a principle that starvation reflected immutable economic and Malthusian law and that had retained a capacity to intervene effectively. In the late $19^{\text {th }}$ and early $20^{\text {th }}$ century cases, with markets now left free to determine allocation, some groups in drought-hit areas ended with no enforceable claims over food. Food flowed instead between regions and social groups purely in response to demand from those with money, locally and internationally, without compensating public action, thus leading to the malnutrition and premature death of millions. Perhaps the casus classicus of such a famine occurred in Ireland in the 1840s, a corner of the then leading country in the world, the United Kingdom, at the precise moment of the triumph of principles of government non-intervention and free trade. It took the lives of ten to fifteen per cent of the Irish population (see e.g. Mokyr, 2006). Such types of 'side-effect' and 'collateral damage' are widespread in an interconnected world (cf. Bauman, 2011). They are marginal only in terms of the attention often given to them, not marginal in their occurrence and human significance. 
Third, besides this 'calculus of pain' (Peter Berger's term), concerning the distribution of costs between people and across generations, is what Berger called the 'calculus of meaning': how far does the acquisition of and preoccupation with material comforts and conveniences bring or jeopardise a fulfilling and meaningful life? The meanings and use of material things depend on people's own values; and material means, important as they are for a life of dignity, are insufficient for a truly human life.

In addressing the calculi of pain and meaning, the choices we face are not between a first option called 'without development' and a second option called 'development', but between many versions and styles of 'development', that differ in terms of destination and of the character of the path towards it. Much of the suffering along past and contemporary paths of development is avoidable. Societally and globally we have real choices. In Latin America, for example, Costa Rica has long illustrated one distinctive and in many ways admirable path (see e.g. Deneulin 2006). Attention to ethics is important for choosing directions and also for understanding behaviour, because people use and are moved by ethical ideas, as we see for example with reference to the growth and impact of human rights thinking.

Fourth, deserving special attention, given the growth of human powers to do good and do harm, are the issues of pain and meaning concerning unborn generations and the already born children who are not yet able to participate in societal decisionmaking. Taking their interests fairly into account, and respecting environmental fragility and constraints, might be called the calculus of sustainability. The Great Transition Initiative, founded by the Stockholm Environment Institute, notes the following areas of critical uncertainties for sustainability: environmental risks, economic instabilities, and socio-political combustibility (Raskin et al. 2002). The three are heavily interconnected, which brings the danger of chain-reaction crises - triggered by climate change, pandemics, financial collapse, mega-terrorism, or key resource shortages - that contemporary institutions will be unable to manage. Karl Polanyi (1957) and others analysed the great transition from agricultural to industrial market society in Europe, and the eventual institutional responses to cope with the enormously disruptive yet productive forces of the 'Unbound Prometheus' (Landes 2003). We now require, concludes the Great Transition Initiative, another great institutional and cultural transition, to more sustainable societies. Building on analyses done for the Earth Charter and elsewhere, it identifies three major types of value change required: from consumerism (the religion of salvation through buying) to a focus on quality of life; from individualism to human solidarity; and to ecological sensitivity, away from attitudes of domination and exploitation of nature (Kates et al. 2006).

Denis Goulet's contribution $(1971,2006)$ was to synthesise and apply all the themes we have mentioned. He was an earlier and perhaps more profound exponent of the notion of 'human development' than the thinkers whose work became embodied in the United Nations Development Programme (UNDP)'s Human Development Reports since 1990 (Gasper 2008a). He articulated a theory of value criteria relevant for assessing development outcomes and processes, and examined the value-conflicts and costs in typical development processes such as technology transfer (Goulet 1977). Goulet became 
the main academic leader of a self-conscious 'development ethics' from the 1960s to 1990s.

\section{What is development ethics?}

\section{1: As questions / responses / an academic field / a self-conscious movement}

'Development ethics' can be considered, in one sense, as a field of attention, an agenda of questions about major value choices involved in processes of social and economic development. It is comparable then to, and overlaps with, business ethics, medical ethics, environmental ethics and other areas of practical ethics. Each area of practice generates ethical questions about priorities and procedures, rights and responsibilities. In this case the questions include: What is good or 'real' development? What is the good life which development policy should seek to facilitate, what really are benefits? How are benefits and costs to be shared, within the present generation and between generations? Who decides and how? What rights of individuals should be respected and guaranteed? When - in for example the garment trade, the sex trade, the 'heart trade' in care services, and the trade in human organs - should 'free choice' in the market be seen instead as the desperation behavior of people who have too little real choice? Besides such issues of policy-level ethics come the numerous ethical tensions and choices in the daily work and interactions of development professionals. (Glover 1995, Goulet 1988, and Hamelink 1997 give fuller statements of agendas for development ethics.)

Development ethics work has arisen as a follow-on to the emergence of self-conscious professional fields - fields that span public policy, programmes, organizations, careers, education, training, research, and sometimes proposed codes of practice - of 'economic development' and development economics, 'social development' and development sociology/anthropology, 'politics of development', and so on, and overall of 'international development' and 'development studies'/ international development studies'. So a preliminary answer to the 'Why?' question is that every field of practice requires a practical and theorised ethics. Such an ethics, in every case, spans from work which is narrowly technical-professional, to work which is more theoretical-academic, to work which engages with wider publics.

The development field is so broad though, that there are limits to the analogy to other areas of professional ethics. The problem arises that development ethics might touch almost everything and so cohere less as an area than do business ethics or medical ethics. This clearly forms no argument against the activity of thinking in an ethically careful way about problems and possibilities in development policy and practice. It means though that this activity may not form a tidy self-enclosed field. The all-encompassing scope of 'development' makes it less a particular specialist area and more a meta-area that aims to link and inform many other areas.

Second, development ethics can be considered also as the diverse body of work that has tried to address the questions mentioned above, and the various sets of answers that are offered. This includes work from long before the label 'development ethics' existed; for 
example, $19^{\text {th }}$ century writers like Henri de Saint-Simon, John Stuart Mill and Karl Marx stated positions on many of the questions. (See e.g. the surveys in Lutz \& Luz 1988, Cowen \& Shenton 1996.) It also includes current work that might not use the name 'development ethics' but addresses various of its questions, such as work by Amartya Sen or Joseph Stiglitz. Peter Berger's famous Pyramids of Sacrifice (1974), stimulated by visits to Mexico and critical interaction with Ivan Illich, described itself as political ethics applied to social change in the Third World.

Third, more narrowly, we have work which uses the name 'development ethics'. Its founder, if any one person should have the title, was the socio-economist Louis Lebret (1897-1966) who led a group called Économie et Humanisme which worked first in France and then in many other countries. The group was formed in 1941 and reflected the experience of the inter-war depression years and a revulsion at avoidable deprivation and suffering in processes of societal advance from which many other people benefit greatly. It sought to contribute to a better postwar world through constructing and applying a more humane vision for economic systems. Through a dialogue between economics, other social sciences, theology and philosophy, Économie et Humanisme promoted a forerunner of the present day idea of human development. Lebret was a lead contributor to Pope Paul VI's encyclical Populorum Progressio, a key source for liberation theology and its 'option for the poor' (e.g., Gutierrez 1971). His group also had important direct impact in Latin American thinking more widely. Variants of its themes of humanization of the economy and of human liberation continue in the writings of contemporary Latin American philosophers and social theorists like Enrique Dussel (1978, 2007).

Similar work emerged elsewhere, including much written in Spanish and Portuguese. Notable for articulating in English these Francophone, Hispanic and Lusophone literatures and connecting them to Anglophone work and new global networks was Lebret's student, the American existentialist and social planner Denis Goulet (19312006), not least through his book The Cruel Choice (1971). Goulet stressed too the importance of understanding faith-based value systems, as held by perhaps most people around the world, especially in lower-income countries (e.g. Goulet 1980); and linked to various perspectives from the South, for example from Buddhist traditions. (See also Gunatilleke ed. 1983.) Development ethics, Goulet proposed, considers the contents of worthwhile development, the acceptable distribution of its costs and risks as well as of its benefits, and the ethical quality of its methods of analysis and practice, including the questions of who should decide and who has responsibility to act.

So a distinct area of work in academic ethics and social philosophy has called itself 'development ethics' since the 1950s (e.g., Goulet 1960, 1965). It attempts to focus on fundamental human priority issues: How well are we (as a society, as a world) doing? Who suffer? Who (does not) gain? Where are we going? Some of this work looks largely only at low-income countries, though with reference also to their relations with highincome countries. Other work recognises that high-income countries are not necessarily highly humanly developed; it looks at poverty and exclusion, emptiness and malaise, indignity and insecurity in rich countries too (e.g. Burgess et al. 2007). 
Nigel Dower distinguishes development ethics by its attention to evaluating societal paths. Traditional ethics has asked "How ought one to live as an individual?". Development ethics asks, he suggests, "How ought a society to exist and move into the future?" (cf. Dower 2008). It is thus a central part of social ethics, while clearly not all of it. Dower stated a similar question for world society, in order to define a sister field of world or global ethics (Dower 2007). One might perhaps equally call that field 'global development ethics'. 'Development ethics' and 'global development ethics' are not really separable: development ethics includes questions about how different societies in the world relate to each other in the process of moving into the future.

Broader than Dower's definition of development ethics is Goulet's: the examination of 'ethical and value questions posed by development theory, planning, and practice'. Its mission is 'to diagnose value conflicts, to assess policies (actual and possible), and to validate or refute valuations placed on development performance' (Goulet, 1997, 1168). Over time there has been growing reference to ethics in discussions on long- and shortterm development policy: in human rights discourse and activism, the Human Development Reports, the Millennium Declaration, and concerns with business corporations' responsibilities and the interests of future generations. Many streams of work in this terrain - including usually the great river of human rights work, or the 'human-scale development' thinking of Manfred Max-Neef and collaborators-have not used the name 'development ethics' but match its description.

Fourth, it is worth highlighting networks and organizations that have explicitly articulated a development ethics agenda and tried to institutionalise the field, via publications, meetings, regular information exchange and courses. The International Development Ethics Association (IDEA), in particular, was formed in 1984 (http://www.developmentethics.org/ ). It has not been oriented only to academic philosophy but been committed to interdisciplinary and policy-relevant work. Working in this style, Crocker, Penz and others (see e.g., Aman, ed., 1991; Crocker, 1991, 2008; Penz et al., 2011) have linked Goulet's thinking to other research traditions, including of human development, human rights and deliberative democracy. ${ }^{2}$

\section{2: Intersections of practice and theorizing, at multiple levels}

There is no single agreed definition of development ethics. This is inevitable, for development ethics lies at the intersection of other fields, each of which brings its own concerns, and the nature of the intersection may change with time. We saw already an example of instead an ostensive definition, which though less elegant is also enlightening: whatever work has used or accepted the label 'development ethics'. But we saw also how this is insufficient: much work on the same issues has not used the label. Let us add then a more structured but still ostensive definition. One can view development ethics work as occurring at the intersections between relevant streams of

\footnotetext{
${ }^{2}$ Surveys of development ethics, by authors active in IDEA, include Crocker (1991), which uses all four definitions above, Schwenke (2008) which focuses on the first (policy challenges), Crocker (2008) which concentrates on the second (academic work on such challenges), and Gasper (2004) which combines the first and second.
} 
theorizing in ethics and relevant streams in development experience and practice. Distinguishable streams of practice concern, for example: socioeconomic development policy, programs and projects; human rights activism and practice; emergency relief, conflict and humanitarian intervention; the world of employment and corporate responsibility; migration; and climate change. Distinguishable families of theorizing (each of which contains diverse strands) include, for example: mainstream moral philosophy; religions; humanism (as drawn on by Goulet, Berger, Illich, Max-Neef or Schumacher); critiques of mainstream economics (such as by Sen and the human development approach, with regard to welfare economics; or critiques of capitalism); well-being research; human rights theory and jurisprudence; feminist theory; and professional/practical ethics, which has become in part a territory of theorizing of its own. Development ethics includes and interconnects each of these multiple sites of reflection. (See Gasper and Truong 2010, for elaboration of this ostensive approach to definition.) Definitions which select and honour only one particular type of ethical theory, for example human rights or the capability approach, are too narrow. Both those types of theorizing are important, but they do not provide everything that is needed, as we will see; and the same applies to any other single ethical tradition.

We can refine the picture by adding a third dimension, for we must distinguish at least the following levels of focus: 1 . International and global relations; 2 . National trajectory and public policy; 3. Organizational conduct; 4. Personal conduct. Dower's definition highlighted the second level: national trajectory. But most treatments of development ethics, including those by Goulet and Crocker, cover all the levels. Indeed, combination of the levels appears essential: one cannot understand issues and choices at any level well without reference also to the other levels.

After the ostensive definitions, let us return to Goulet's proposed explicit definition, as helpful, manageable and still relevant: the examination of ethical and value questions posed by development theory, planning, and practice, in order to diagnose value conflicts, assess policies, and assess valuations placed on development performance (Goulet 1997).

Standard topics in development ethics then include debates about:

- the values proposed as constituting the meaning of human-, societal- and/or global- development and as requiring respect, prioritisation and incorporation into legal frameworks and/or public action; including principles concerning priority goods (and bads) and their distribution, and by what processes decisions should be made;

- evaluation of experiences and proposed action alternatives;

- methods and methodologies for such discussion, analysis, design, evaluation, incorporation and action.

The recent volumes by Crocker (2008) and Penz, Drydyk and Bose (2011) constitute mature examples of work with this agenda.

It is worth underlining the context in which these debates arise. Development ethics looks at challenges and costs of processes of development and change in a world context of, first, great possibilities for promotion of human well-being but very incomplete systems of rights and responsibilities to fulfil this potential; second, extreme global inequalities, that 
constantly affect and distort life and action in 'the South'; third, extreme inequities globally, in the senses that much of the past record of change has involved oppression in and of the global South and that present-day citizens in the North inherit privileges that they have not individually done much to earn; and fourth, considerable shared risks — of and from climate change, conflict, pandemics, etc. — of harms that will typically hit the weakest groups the hardest (see e.g. UNDP 2007).

\section{Objections to development ethics}

\subsection{Objection 1: Does it generate only endless proliferation of different opinions?}

Some critics hold that ethics is a matter of taste, and that tastes differ dramatically and incorrigibly. In reality, we observe some considerable and gradually growing areas of consensus, nationally and internationally, including to a slowly growing extent regarding human rights; and within specific decision-making areas we find valuable opportunities for fruitfully 'dealing with differences' (Forester 2009). Peter Penz (1991) and Mozaffar Qizilbash (2002), amongst others, point out that while differences exist between leading perspectives that have evolved and/or been widely employed in development ethicssuch as theories of needs, of prudential values, Sen and Nussbaum's variants of a capabilities approach, and the theories of John Rawls on primary goods and John Finnis on basic goods - these perspectives have extensive areas in common and even more extensive shared implications. Similarly, when Penz (2003) analyses the ethics of forced displacement due to development projects, he shows the strengths of a methodology of applied ethics that 'focuses on generalisable principles, but does not commit itself to a particular normative theory' (Penz, p.142). He uses this intermediate methodology to build arguments that can command support from many different normative theories, regarding the responsibilities of various domestic agents and foreign agents in cases of actual or threatened forced displacement. ${ }^{3}$ Sen has expounded and applied a similar pragmatic approach (e.g. Sen 2009, chs. 4, 18). In other words, we do not need universal acceptance of one specific detailed ethical theory in order to make progress in ethical choices. Absence of such acceptance does not leave us to rely only on intuition or locally regnant values.

Nobel Prize winner Joseph Stiglitz shows similarly how a pragmatic methodology can offer scope for quite widely persuasive evaluations. For assessing the operations of rich country governments and the international organizations that they control, in their dealings with low-income countries, Stiglitz (2005) adopted a set of ethical precepts that he did not seek to prove but could plausibly claim command wide acceptance. The precepts are: honesty (including no withholding of important information); fairness (in the sense of treating similar cases similarly); social justice (in the minimal sense of respecting basic needs, including needs for dignity); and responsibility (including taking

\footnotetext{
${ }^{3}$ Using this approach, Penz, Drydyk and Bose (2011) present a system of ethics for cases of threatened or actual displacement. It amends and extends the perspective advanced by the World Commission on Dams (2000). They derive ethical guidelines for local, national and international responsibilities, with special reference to dam projects, on the basis of a proposed synthesis of core values found in United Nations and other work, that they suggest constitutes a widely accepted consensus 'human development ethic'.
} 
into account, and being accountable for, the external effects that one causes). Honesty and responsibility imply that we should make clear the limits of the information and understanding from which we advise, or press, others to act. This has often not been done by international financial institutions and rich country governments in their relations with developing countries. Instead they have typically relied on their financial muscle to enforce their prescriptions, such as for full mobility of capital, and left the risks to be borne by the weakest parties. They have also not treated like cases alike: arguments about social dislocation which rich countries have used to block global free movement of labour have been waved aside when used by developing country governments to argue against global free movement of capital. Stiglitz's review of the conduct of the international financial institutions and international development agencies in the 1990s led him to a further precept: maintain rather than tear apart the existing fabric of social norms and cooperation. He found this principle to have been grossly violated in the shock economic reforms during that decade that destroyed the value of ordinary people's pension rights in Russia while distributing huge wealth to a new priviligentsia. Elsewhere he argues for more and deeper democracy at all levels (Stiglitz 2007).

\subsection{Objection 2: Is it an expensive luxury that undermines real development?}

One might grant that the concerns highlighted in development ethics are valid, and that argumentation about responsibilities and responses may in some cases be able to command wide support. Still, one can ask: what is the relative importance of such concerns? Does a preoccupation with them get in the way of 'real development'-notably, economic growth - and is that not the best solvent of all such problems, which arise as side-effects of scarcity and backwardness? Answering this objection leads us to consider both the relative importance of the concerns as independent values and their instrumental significance.

The British historian R.H. Tawney (1880-1962) proposed that:

"The most obvious facts are the most easily forgotten. Both the existing economic order and too many of the projects advanced for reconstructing it break down through their neglect of the truism that, since even quite common men have souls, no increase in material wealth will compensate for arrangements which insult their self-respect and impair their freedom. A reasonable estimate of economic organization must allow for the fact that, unless industry is to be paralysed by recurrent revolts on the part of outraged human nature, it must satisfy criteria which are not purely economic" (Tawney 1926: 284; cited by McCann 2003: 196).

Tawney's estimate receives support from many polls and studies of well-being, such as the World Bank's Voices of the Poor project. The three Voices of the Poor volumes (Narayan, Patel, et al. 2000; Narayan, Chambers et al. 2000; Narayan and Petesch 2002) presented views about well-being and ill-being expressed by over 60,000 respondents around the world. Economic growth is found to be no guarantee of human well-being. Beyond higher middle-income levels wealth and income are not even substantially correlated with either subjective well-being or many aspects of objective well-being (Bruni and Porta eds. 2007). 
These findings about the felt independent importance of ethical concerns have corollaries in terms of their instrumental significance. If we wish to understand and influence human behaviour, then we need to think about ethics, among other matters; for people are in part motivated and guided by ethical ideas, among other types of idea. If people feel that they are treated unfairly, in terms of the ethical principles they subscribe to, this affects their motivation and cooperation and can lead to conflict. Since people engage seriously in ethical debate and are moved by ethical beliefs, looking closely at ethics is an essential part of good explanatory work too, Amartya Sen reminded economists in his On Ethics and Economics (1987). Similarly, attention to and respect for people's ethical beliefs has instrumental importance for designing effective styles of intervention and interaction.

Methods of interaction that do not respect what participants consider to be their rights, including their rightful degree of autonomy, are likely to undermine their commitment and involvement. David Ellerman's Helping People to Help Themselves (2005) looks at how processes employed in development cooperation affect the growth of recipient autonomy. He concludes that autonomy-promoting assistance turns out to be very close to rights-respecting assistance. Unhelpfully intrusive 'help', whether it is 'help' that replaces beneficiaries' own activity or 'help' that dictates their pattern of activity and hence replaces their decision-making, simultaneously offends their felt rights to be active makers of their own lives and leaves underutilised their capacities, knowledge and will. The negative effects of these two lines of counter-productive 'help' then reinforce each other in scenarios of apathy and resistance, leading to wasteful use of resources and frequent failures to fulfil objectives.

Discussion of ethical questions and principles is sometimes felt as embarrassing precisely because rather than being a luxury it touches on fundamentals of identity and motivation. As human beings we undertake our lives using notions about what are appropriate ends and rights and due respect, and those ideas demand attention: for understanding behaviour, for in negotiations, and for motivation. As recognised by Berger in his emphasis on the calculus of meaning, and by Tawney from his review of history, according people dignity is not a luxury; nor is it very expensive. People feel it as a basic need, and to neglect it is liable to be far more expensive, for neglect triggers conflict. This principle underlies the United Nations Charter: 'the explicit linkage of human rights protections to an international order of peace and security. ... Collective security now [is] seen to require the defense of human rights norms and principles' (Quataert 2009, 40). Articulating the principle has become part of the 'human security' approach, as sister to conventional human rights advocacy.

\subsection{Objection 3: Why bother, when we already have the human development and capability approach and/or the human rights tradition?}

Human development thinking, as formulated by Mahbub ul Haq, Paul Streeten and others and incorporated in the work for the global, national and regional Human Development Reports, contains both an ethical perspective and a theory of interconnections. Both arose in reaction to the traditional perspective in economics. The principle of interconnection 
holds that many linkages that are not mediated and measured through economic means are very important, including for economic life: for example, the linkages from lopsided income distribution to malnutrition to reduced learning capacity and lower lifetime earning capacity, or the linkages from skewed international trading systems to societal stresses and conflict in low-income countries. As we saw, this principle of interconnection widens the ethics agenda and requires wider scope in explanations too. It brings a focus on the 'side-effects' that damage some people, for example, when greater purchasing power and greater political power for some groups makes food unaffordable for weaker groups or leads to their displacement from lands that more powerful people now desire (see e.g. Blaser et al., 2004).

Human development theory's ethical perspective, the capability approach, holds that the ethical principles embodied in market-based economics do not suffice for public policy; instead market values are deemed important primarily insofar as they support humanly valuable 'be-ings' and 'do-ings'. This component in human development theory is vital, but is far from giving a full ethical basis; for example, for how to handle conflicts between and within different people's valued 'be-ings and do-ings'. Capability theory explicitly declares that it is not a full ethical system. Human development theory formulated in terms of a capability space emphasises that space, but tells us nothing about what within such a space is valuable; though it rightly rejects the idea that everything whatsoever in this space is valuable.

To think about the ethical meaning(s) of 'human', and about trade and sweated labour, forced displacement or professional ethics, human development thinking must draw on longerstanding discussions. The ethical traditions that should be consulted lie not only in mainstream Anglo-American academic philosophy (see e.g., Cameron \& Ojha 2007; Giri 2002, Hamelink ed. 1997, Quarles van Ufford \& Giri eds. 2003, for some attempts to cast the net wider); and they include not least the decades-long development ethics tradition of Lebret, Goulet, and those influenced by their approach (see e.g.: Lebret, 1967; Goulet 1971; Esquith \& Gifford eds. 2010; Ethics and Economics, vol. 4(2), 2006; Schwenke 2008; Wilber \& Dutt eds. 2010).

What exactly is the relationship of development ethics to human rights, an older and larger tradition than the work that has explicitly called itself development ethics? Tawney defined the whole humanistic tradition in terms of its treatment of material inputs and wealth 'as means to an end, and that this end is the growth towards perfection of individual human beings' (cited by Lutz 1992a, 98). Lutz called this 'a welfare standard explicitly expressed in terms of human welfare rather than "economic" or "social welfare"" (1992a, 103). He summarized the welfare standard as 'material sufficiency and human dignity for all' (1992b, 166), further summarized as respect for basic human rights. Human rights ideas have become a language with which nearly everyone is able and willing to communicate and around which most people can unite. However, reflecting the growth of separate bureaucracies for development, human rights, peacekeeping and emergency relief from the mid $20^{\text {th }}$ century, separate lines of work were cultivated for several decades (Murphy 2006; Quataert 2009). From the 1990s the gap has considerably reduced, in part through the leadership provided in the late 1990s by 
the then UN Secretary-General Kofi Annan and then UN High Commissioner for Human Rights, Mary Robinson. Also the work on human development and human security led by Mahbub ul Haq, Amartya Sen, Richard Jolly, Martha Nussbaum and others has helped to link development thought to the project of universal human rights (Jolly et al. 2009).

While thinking in terms of human rights provides a central strand in development ethics it does not fit or suffice for all the issues, contexts and tasks that we face. Human rights theory has a largely individualistic orientation. Different human rights can conflict and require prioritization, yet the rights tradition generally insists on inviolability. Too many claims can become asserted as inviolable human rights, including even property rights, not least 'intellectual property rights'. Defining definite duties that correspond to asserted rights is often problematic. Prioritization, duty-specification and enforcement have conventionally relied in large part on a cumbersome legal system which is far more accessible to the rich and powerful (Gasper 2007). Rights language in isolation is thus at risk of becoming rigid and legalistic, set in forms and institutions which in practice often exclude poor people.

We require a richer value basis than only rights or only capabilities or the two together. Not all relevant values can be thought of in terms of rights and duties; we need attention also to virtues and to processes of equitable and respectful negotiation (Held 1995; O'Neill 1996; World Commission on Dams 2000; Forester 2009; Penz et al. 2011). The value basis must include attention to the grounds, processes and formats of ethical reasoning, and also to attitudes of caring and commitment.

Capability is only one aspect of humanity. Vulnerability is another, as emphasised in human security analysis and in Goulet's The Cruel Choice (1971), in which the second chapter was entitled: 'Vulnerability: the key to understanding and promoting development'. One reason why human security thinking has gathered momentum is that it integrates the languages of capability, rights and security. It elaborates the foundational principle of the United Nations that without respect for basic human rights there will be no sustained security. Underlying that principle is a deeper picture of human personality, emotion, sociability and lived experience than has been used in some thinking on human rights and human development (Gasper 2009, 2010). The approach makes us ask: What is the 'human' minimum that each person has a right to secure, beyond possession of a set of reasoned preferences and capacities for choice? An exploited garment worker and the seller of a kidney may have made informed and reasoned choices. Similarly, in thinking about responsible lifestyles, or respectful (and therefore more effective) forms of advice and influence, or in trying to understand and counteract corruption, we can draft and use codes of rights and duties but we also need much more. Human security thinking helpfully connects also to the roots in humanistic psychology, humanistic philosophy and daily moral life that fed Goulet's thinking and related work in development ethics.

\subsection{Objection 4: Does development ethics ever have any impact?}

Moral arguments may have little force to change policy and action if they remain 'external critiques' not absorbed into accepted 'expert' knowledge, and if the ethical 
critiques come from diverse sources with little recognition, understanding and respect for each other. How can ideas with broad appeal and yet practical applicability be crafted, promoted and absorbed? The now widely accepted definition of development as centering on how people can live as judged by a range of human values - from basic material needs through a range of higher aspirations for expression, self-realization and dignity - was clear in the work of Lebret in the 1950s and Goulet in the 1960s to 1980s, but became more influential only in the 1990s when taken up by a network led by a well situated and charismatic policy entrepreneur (Mahbub ul Haq) who seized on a favourable combination of circumstances in order to institutionalise this conception, in the Human Development Reports and related activity (Haq and Ponzio 2008; Gasper 2011).

Grander examples offer lessons too, from the decades-long campaign against slavery that was eventually successful despite the continuing economic profitability of slave-trading and slave-ownership (Crawford 2002), through to the debt-relief campaigns of the 1990s and recent years. Hanlon (2000) shows how the Jubilee 2000 campaign that led to lightening of debt burdens applied ideas of basic needs, fair process and human rights to the debt crises in the poorest countries. He reviews the history of credit, debt, default, and debt relief or forgiveness or repudiation, through the $19^{\text {th }}$ and $20^{\text {th }}$ centuries. Periodic default or relief can be seen as a normal, occasional hazard inherent in the overall richly profitable history of lending. However, the same countries in the North that had defaulted or repudiated debts at various times in the $19^{\text {th }}$ and early $20^{\text {th }}$ centuries were to the fore in the late $20^{\text {th }}$ century in enforcing repayment of external debts by low-income countries that were in economic crisis, driving them to cut their already low expenditures on basic services for water, health and education. The debtor and creditor countries are signatories to the Universal Declaration of Human Rights. The main victims of the cuts were poorer people and children who bore no responsibility for the debts, which had sometimes been corruptly arranged. But financial power brings influence, both direct and indirect; thus rich country governments have feared to let the biggest irresponsible lenders collapse, because of envisaged knock-on effects, and have given priority to supporting them. Stiglitz (2005) shows how the IMF and its lead member, the US government, have repeatedly prioritised bailing out rich lenders while cutting or diverting resources from poor people in poor countries. The Jubilee 2000 campaign's historically-informed critical analyses in terms of basic needs and associated human rights achieved significant impact in countering this bias. Various subsequent campaigns for economic, social and health rights have also made progress, while still having far to go.

At the levels of development projects and local resource-allocation too, experiences in various countries such as Brazil in popular participation in decision-making, including around dam construction and in participatory municipal budgeting, show how ethically inspired and informed social movements can and do make a difference (see e.g. Goulet 2005). Fora of globally and locally networked activism, such as the World Social Forum, have shown that 'another globalization is possible', at least to some useful degree. 


\section{From What and Why to How: some suggestions}

\subsection{A 'means of the means'}

Denis Goulet argued that, in order to make a major difference, ethical thinking must become 'the means of the means': 'a moral beacon illuminating the value questions buried inside instrumental means appealed to by decision-makers and problem-solvers of all kinds' $(1988,157)$. Since the fate of general intentions depends upon the character of the concrete means which are available and assigned to fulfil them-the institutions, rules, persons and procedures - so ethical ideals must become well embodied in those concrete means, and must pervade and guide their detailed operation. The agenda for development ethics includes therefore not just ethical theorising but attention to its linkages to attitudes, public action and policy making, to the work of national and global institutions and civil society, and to practice-related ethical thinking in these settings. Ethics needs to be incorporated into codes, training, policy and planning routines, laws and legal process, public debate, and communication strategies.

Professional codes have a role (see, e.g., Inter-American Initiative 2007). Development economists work on issues marked by major uncertainty and wield major influence on the lives of vulnerable people. Yet, unlike in most other professions, they are not inducted into or held accountable by a professional code of practice. They should be obliged to make clear the degrees of uncertainty in their understanding and to take into account the vulnerability of poor people to unwanted effects resulting from their advice and decisions (Stiglitz 2005). George DeMartino has specified major elements of such a code (2005, 2010). If not partnered though by a readiness of spirit, codes can remain dead letters.

McNeill and St.Clair (2009) warn that much 'development' activity has become a sort of business: a specialised arena dominated by 'expert' professionals and by 'agencies' dealing with 'recipients'. ${ }^{4}$ These experts share an arcane language in which fundamental ethical issues and reflection on the costs and risks of their planning are absent or, when present, stripped of any direct and painful human content. The role of economists in defining and framing development issues is especially important, for they hold central roles within development bureaucracies, present their frameworks as value-free, and often reject ethical issues as being outside the scope of their science and planning (McNeill and St.Clair 2009). In particular, market prices have been widely accorded a status like meteorological data that must simply be observed and respected. The task for development ethics, in contrast, is to make questions like 'What is the human rights price for water ?'- posed by a student who was perturbed by market-derived prices for water that are unaffordable by the poorest groups--seem as normal as the question of what is the market price or the direct cost recovery-price. But whereas 'embedded ethicists' are now not uncommon in medical organizations, the field of economic and social development remains riddled with resistance to ethical thinking and queries as to its legitimacy and value-added. For development ethics raises issues about fundamental features of intraand inter-national systems of power and is thus not just one more area of applied ethics.

\footnotetext{
${ }^{4}$ This paragraph and the next draw partly on material drafted by Asuncion Lera St. Clair.
} 
St. Clair (2007) calls too for investigation of the processes of authoritative knowledge production. Ethical thinking must be complemented with epistemological reflection, on how different cognitive and social values guide attention and research choices, and how the choices of these values, implicit or explicit, are influenced by power relations. Boaventura de Sousa Santos (2007) argues that 'cognitive justice'-the democratization of expert knowledge and openness to alternative non-Western and non 'expert'-based knowledge - is vital for construction of feasible and attractive alternative futures.

The most fundamental 'means' that should be imbued by a development ethic may well therefore be professionals, at various levels. Chambers (1997a, 2005) discusses elements of an informal professional ethic, an ethos of ethical development:- sensitivity to the power of language and to who controls it, and a search for effective generative concepts; an openness to listening, which is the most important influence on the use of techniques of participatory research and planning, far more important than the technical details; and an openness to self-criticism, including about one's own lifestyle, and to learning how to be more while having less. These themes are taken further by, amongst others, Hamelink (1997), Giri (2002), and Crocker (2008).

Some authors consider that such perceptions can be dramatically promoted by short 'immersion visits' in which development professionals spend some days or weeks living with poor people (Irvine et al. 2004). Such visits must at least be complemented by attention to the methods that the professionals have available in their subsequent operations, and attention in earlier stages to their prior education. Teaching in schools and general citizen education are by far the largest arenas, but academics' role there is at best indirect. Within university teaching, some development ethics textbooks are now available, designed for teaching separate optional courses. While such courses can attract keen minority audiences, and provide opportunities to train future potential key resource persons and to develop ideas, ultimately more important probably is to exert influence within mainstream and compulsory courses in public policy, development economics, research methodology, and the like.

\subsection{Incorporation in methodologies of policy analysis and planning}

Crocker (2008) calls for a shift in primary emphasis in development ethics work 'From Moral Foundations to Interpretative and Strategic Concepts'. Many urgently needed changes can be justified from several types of moral foundation. More important then than further ethical theorizing is conversion of ethical insights into practical and flexible working methodologies for value-conscious investigation, design and evaluation, to help to guide policy and action. Multi-criteria evaluation methods offer a democratic deliberative alternative or partner to cost-benefit analysis, giving more space for reflection on value-choices, uncertainties and who will bear the expected and possible costs. Hoksbergen (1986) demonstrates methods for drawing out the world views and assumptions within given methods of development policy analysis, and then methods for proceeding in the opposite direction: beginning with a specified world view and/or ethical perspective and working out its possible implications for methods and procedures of 
policy analysis. Human rights-based approaches provide a key example, having moved beyond only lists of human rights norms that are somehow to be legally defended, towards using human rights ideas to influence all stages and phases of practice.

Crocker's own example is Amartya Sen and Jean Drèze's use of capabilities analysis to strategically redirect development policy analysis, illustrated at book length in their studies of hunger and public action (1989) and of development challenges and options in India (2002), and in some of UNDP's work on human development. Gasper (2008b) attempts to formalize the implied methodology. Jolly and Basu Ray (2007) show how the related theme of human security has been applied by a series of national Human Development Reports: through a case-specific focussing on the particular threats to the particular priority aspects of life that are felt to be at risk in the place and time concerned; and wide ranging analysis then of those factors' causes and effects. The reports demonstrate how such a value-led transdisciplinary approach can both retain a manageable scope of attention and yield major findings: for example about how certain types of economic policy may generate serious morbidity and mortality impacts amongst poorer groups.

Evident in both the Sen-Drèze approach and the human security work is case-specific deliberation about which priorities will focus and guide investigation, program design and evaluation. This is seen too in the basic needs theory created by the Chilean Green economist and politician, Manfred Max-Neef, that is influential in some community development work worldwide (Max-Neef et al. 1989, 1991). It gives a rich format for discussing life-situations and priorities in a community, aiming 'to promote the transformation of an object-person into a subject-person' (Max-Neef 1992, 198). More widely, work on deliberative methodologies and multi-level societal deliberation about development choices (see e.g., Cameron and Ojha 2007; Chambers 1997b, 2008; Crocker 2008; Forester 2009) and on promotion of personal and group agency and autonomy (e.g., Ellerman 2004, 2005; Pick \& Sirkin 2010) provides suggestions for how to counter inequalities in voice between technical specialists, local and international elites, and ordinary and poor people. Natural partners for these forms of analysis are social movements that represent or support the claims of the weakest groups in national and global society.

\subsection{Development ethics in the public arena}

Development ethics work should function as an interdisciplinary meeting ground where diverse disciplines, concerns and approaches interact, rather than primarily as an academic subdiscipline in philosophy. Only in this way can it have wider impacts on methods, movements and education. Since ethics is a branch within philosophy, development ethics work has occurred partly as one niche of practical ethics within university worlds. However, just as environmental ethics is certainly not only engaged in by disciplinary philosophers, work on development ethics involves people from a wide range of backgrounds, including practitioners and scientists of many types. The required types of interaction and immersion, in particular contexts each with their own reality, and in trying to understand and influence the methods and systems that structure routine 
practice, must be undertaken by people who remain well connected to those specific professional and/or disciplinary areas.

So while Goulet's vision of the scope of development ethics remains sound, his ideas about organisational format require reconsideration (Gasper 2008a). Ethics as the 'means of the means' is effected situation by situation, in particular professional, physical and social niches, rather than by a cadre of super-generalists. At the same time, a widely influential development ethics requires also robust general theories-including of needs, human rights, capabilities, and deliberative democracy, and of how such frameworks connect - in order to motivate and guide action and to communicate across wide spans of professional and physical territory.

Human rights work already illustrates the required combination and articulation of activities. Besides the traditional locations in political philosophy and academic and applied jurisprudence, human rights-based approaches have a broader field of operation: seeking to directly influence public policy and action by businesses, individuals, and civil society and community groups. For example, in trying to promote basic rights like the rights to sufficient food and sufficient clean water, in situations with no single clear-cut and capable duty-holder, attention now centres less on continued refinement of an ethical case, and rather on building a human rights culture marked by principles of universality, accountability, non-discrimination and empowerment, that helps to ensure that the ethical case is not marginalised by 'narrow economistic and political' concerns (Hansen \& Sano 2006, 54). Human rights campaigning seeks to enter the thinking of voters and consumers, gradually affect public consciousness and conscience, and directly and indirectly influence the actions of governments, businesses and all manner of organizations: for example, to support the provision and subsidy of school lunches for children from low-income families as a way to operationalise the right to food.

Agencies which engage in human rights-based campaigning are aware of the skills required for public communication, for cooperating with policy agencies and (other) social movements, and for grasping attention through effective keywords, indicators, and evocative instructive examples. Academics working on development ethics face comparable demands, including how to be heard in mainstream journals, popular media and social movements, and how to maintain in-depth work while avoiding the trap of speaking only to the converted.

\subsection{Being ready for crises}

As the world rethinks 'development' in light of the challenges of sustainability, the past and ongoing work on development ethics will be an important resource for the needed transformations. In one type of scenario, thoughtful and effectively communicated development ethics work could contribute to help steer humanity's ships away from iceberg(s) of pain, misery and possible societal collapse. In another type of scenario, only absolute crisis will trigger the institutional and intellectual momentum for major change. We cannot tell in advance what mixture of these scenarios will eventuate. The Great Transition Initiative's work (e.g. Raskin et al. 2002) models various detailed scenarios, 
that differ according to the combination of (a) intensity of crisis and (b) degree of coping capacity. It considers that global coping capacity can only be greatly increased if a powerful global citizens movement emerges, combined with sufficient shared vision, a shared identity of global citizen, and a realistic change strategy. 'Turbo-capitalism' (Luttwak 1999), driven by unlimited desire for financial profit, ever increasing concentrations of money capital, ever growing spread of the commodity form, and the distancing of the powerful from responsibility for and exposure to 'collateral effects', may not readily self-reform. Only given a powerful and well-oriented global citizens movement will even a modest policy reform scenario make much progress, concludes Raskin (2006).

Disturbingly, the degree of progress made in instituting a global human rights regime since 1945 fits the second type of scenario, of response only after being embroiled in crises and disaster, probably better than the first type, of timely and humane anticipation and prevention. Conferences and publications on perpetual peace and 'the rights of man' did not avert the disasters of the First and Second World Wars and other holocausts of the late $19^{\text {th }}$ and first half of the $20^{\text {th }}$ century. They did though prepare an intellectual and organizational infrastructure that was available to build on when global leaders in the 1940s sought a new order that could avoid future such disasters (Quataert 2009). This illustrates a standard pattern in institutional reform: change may come only after an old system enters into severe crisis that hurts also its rulers and supporters. At that stage the proponents of change must be ready with viable alternatives that have an ethical rationale but have also been convincingly presented and elaborated in terms of consolidated language, methods and actionable plans.

Work in development ethics should prepare for both types of scenario. Social change happens in many ways. It typically comes either slower than we expect or faster than we expect. This can apply both for undesirable as well as desirable change. The required preparations include strengthening of exchange with various ethical traditions around the globe; engaging better with the realms of activism and practice that seek global justice; and essaying further influence in policy and action through strategies and methodological tools that consciously incorporate ethical thinking.

$* *$ 


\section{References}

Aman, K. (ed.). 1991. Ethical Principles for Development: Needs, Capacities or Rights? Montclair, NJ: Institute for Critical Thinking at Montclair State University.

Bauman, Z. 2011. Collateral Damage - Social inequalities in a global age. Cambridge: Polity.

Berger, P. 1974. Pyramids of Sacrifice: Political Ethics and Social Change. New York: Basic Books.

Berman, M. 1983. All That Is Solid Melts Into Air: The Experience of Modernity. London: Verso. $2^{\text {nd }}$ edition, 2010.

Blaser, M., H. Feit and G. McRae (eds.). 2004. In the Way of Development - Indigenous Peoples, Life Projects and Globalization. London: Zed.

Bruni, L., and P.L. Porta, eds. 2007. Handbook on the Economics of Happiness. Cheltenham: Edward Elgar.

Burgess, J.P., et al., 2007. Promoting Human Security: Ethical, Normative and Educational Frameworks in Western Europe, Paris: UNESCO.

Cameron, J., and H. Ojha. 2007. A deliberative ethic for development,- a Nepalese journey from Bourdieu through Kant to Dewey and Habermas, International J. of Social Economics, 34(1/2): 66-87

Cernea, M. 2006. Remarks at symposium on the Global Environmental Facility; Institute of Social Studies, The Hague, 17 January.

Cernea, M., 2008. Compensation and investment in resettlement. In: Can Compensation Prevent Impoverishment? Eds. M. Cernea \& H.M. Mathur, New Delhi: Oxford University Press.

Chambers, R. 1997a. Responsible Well-Being: A Personal Agenda for Development, World Development, 25(11): 1743-54.

Chambers, R. 1997b. Whose Reality Counts? Putting the First Last, London: Intermediate Technology Publications Ltd.

Chambers, R. 2005. Ideas for Development. London: Earthscan.

Chambers, R. 2008. Revolutions in Development Inquiry. London: Earthscan.

Cowen, M.P. and C.W. Shenton. 1996. Doctrines of Development. London: Routledge.

Crawford, N.C., 2002. Argument and Change in World Politics. Cambridge: Cambridge Univ. Press.

Crocker, D.A. 1991. Towards Development Ethics, World Development 19(5): 457-483.

Crocker, D.A. 2008. Ethics of Global Development-Agency, Capability and Deliberative Democracy. Cambridge University Press.

Davis, M. 2001. Late Victorian Holocausts: El Niño Famines and the Making of the Third World. London: Verso.

DeMartino, G. 2005. A Professional Ethics Code for Economists. Challenge 48(4): 88-104.

DeMartino, G. 2010. The Economist's Oath: On the Need for and Content of Professional Economic Ethics. New York: Oxford University Press.

Deneulin, S. 2006. The Capability Approach and the Praxis of Development. Basingstoke: Palgrave Macmillan.

De Sousa Santos, B. (ed.) 2007. Cognitive Justice in a Global World: Prudent Knowledges for a Decent Life. London: Lexington Books.

Dower, N. 2007. World Ethics, $2^{\text {nd }}$ edition. Edinburgh: Edinburgh Univ. Press.

Dower, N. 2008. The Nature and Scope of Development Ethics. Journal of Global Ethics 4(3), 183-193.

Drèze, J. and A. Sen. 1989. Hunger and Public Action, Oxford: Clarendon.

Drèze, J. and A. Sen, eds. 1990. The Political Economy of Hunger (3 vols.). Oxford: Clarendon.

Drèze, J., and A. Sen. 2002. India: Development and Participation. Delhi: Oxford Univ. Press.

Dussel, E. 1978. Ethics and the Theology of Liberation (trans. B. McWilliams). New York: Orbis.

Dussel, E. 2007. Política de la Liberación: Historia Mundial y Crítica. Madrid: Editorial Trotta.

Ellerman, D. 2004. Autonomy-Respecting Assistance - Toward an Alternative Theory of Development Assistance. Review of Social Economy, 62(2): 149-168.

Ellerman, D. 2005. Helping People to Help Themselves: From the World Bank to an Alternative Philosophy of Development Assistance. University of Michigan Press.

Esquith, S., \& F. Gifford, eds. 2010. Capabilities, Power and Institutions: Towards a More Critical Development Ethics. Pennsylvania State University Press.

Ethics and Economics, 4(2) [http://ethique-economique.net/Volume-4-Issue-2.html]. Selected papers from the 2006 International Development Ethics Association conference in Uganda.

Forester, J. 2009. Dealing with Differences. New York: Oxford University Press. 
Gasper, D. 2004. The Ethics of Development, Edinburgh: Edinburgh University Press.

Gasper, D., 2007. Human Rights, Human Needs, Human Development, Human Security. Forum for Development Studies, 2007/1: 9-43.

Gasper, D. 2008a. Denis Goulet and the Project of Development Ethics: Choices in methodology, focus and organization. Journal of Human Development, 9(3): 453-474.

Gasper, D. 2008b. From 'Hume's Law' To Policy Analysis For Human Development. Review of Political Economy, 20(2): 233-256.

Gasper, D. 2009. Global Ethics and Human Security. In Vol. 1 of Globalization and Security: an encyclopedia, eds. G.H. Fagan \& R. Munck, 155-171. Westport, CT: Greenwood.

Gasper, D. 2011. 'Pioneering The Human Development Revolution' - Analysing The Trajectory Of Mahbub ul Haq. Journal of Human Development and Capabilities, 12(3): 433-456.

Gasper, D., and A. Lera St. Clair. 2010. The field of development ethics: Introduction, in Gasper and St. Clair (eds.), Development Ethics, xiii-xxxiii, Aldershot: Ashgate.

Gasper, D., and T-D. Truong. 2010. Development Ethics through the Lenses of Caring, Gender and Human Security. In Capabilities, Power and Institutions, eds. S. Esquith and F. Gifford, 58-95. Pennsylvania State Univ. Press.

Giri, A.K. 2002. Conversations and Transformations: Toward a New Ethics of Self and Society. Lanham, MD: Lexington Books.

Glover, J., 1995. The Research Programme of Development Ethics. In Nussbaum, M. and J. Glover, eds. Women, Culture, and Development, 116-39. Oxford: Oxford Univ. Press.

Goulet, D. 1960. Pour une éthique moderne du développement. Développement et Civilisations, 3, September: 10-23. [Translated into English in Goulet (2006).]

Goulet, D. 1965. Etica Del Desarrollo. Barcelona/Montevideo: Editora Estela/IEPAL.

Goulet, D., 1971. The Cruel Choice. New York: Atheneum.

Goulet, D. 1977. The Uncertain Promise: Value Conflicts in Technology Transfer. New York: IDOC.

Goulet, D. 1980. Development Experts: The One Eyed Giants, World Development, 8 (7/8):481-9

Goulet, D. 1983. Mexico: Development strategies for the future. Notre Dame, IN: University of Notre Dame Press.

Goulet, D. 1988. Tasks and Methods in Development Ethics. Cross Currents, 38(2): 146-163.

Goulet, D. 1997. Development Ethics: A New Discipline. International Journal of Social Economics 24(11): 1160-1171.

Goulet, D. 2005. Global Governance, Dam Conflicts, and Participation. Human Rights Quarterly, 27: 881907.

Goulet, D. 2006. Development Ethics at Work: Explorations 1960-2002. New York: Routledge.

Gunatilleke, G., N. Tiruchelvam, and R. Coomaraswamy, 1983. Ethical Dilemmas of Development in Asia. London: Lexington Books.

Gutierrez, G. 1971. A Theology of Liberation. Orbis.

Hamelink, C., 1997. Making Moral Choices in Development Co-operation: The Agenda for Ethics. In Hamelink (ed., 1997), 11-24.

Hamelink, C. (ed.), 1997. Ethics and Development - on making moral choices in development co-operation, Kampen, Netherlands: Uitgeverij Kok.

Hanlon, J. 2000. How Much Debt Must Be Cancelled? J. of International Development, 12: 877-901.

Hansen, J.K. and Sano, H-O. 2006. The Implications and Value Added of a Rights-Based Approach. In B. Andreassen and S. Marks (eds), Development as a Human Right, 36-56. Harvard School of Public Health. Nobel Symposium 125.

Haq, K., and R. Ponzio, (eds. 2008. Pioneering the Human Development Revolution: An Intellectual Biography of Mahbub ul Haq. Delhi: Oxford University Press.

Held, V. (ed.) 1995. Justice and Care: Essential readings in feminist ethics. Boulder: Westview.

Hoksbergen, R. 1986. Approaches to Evaluation of Development Interventions - the importance of w.rld and life views. World Development, 14(2): 283-300

Inter-American Initiative on Social Capital, Ethics and Development. 2007. Formulating and Implementing an Effective Code of Ethics - Comprehensive Guidance Manual, ATN/ED-9535-RG. Washington, D.C.: Inter-American Development Bank.

Irvine, R., R. Chambers, R. Eyben. 2004. Learning from Poor People's Experience: Immersions. Brighton: IDS Sussex. 
Jolly, R., and D. BasuRay, 2007. Human Security - national perspectives and global agendas - Insights from National Human Development Reports. J. of International Development, 19(4): 457-472.

Jolly, R., L. Emmerij \& T.G. Weiss. 2009. UN Ideas That Changed the World. Bloomington, IN: Indiana University Press.

Kates, R., et al. 2006. Great Transition Values - Present Attitudes, Future Changes. Great Transition Initiative. http://www.gtinitiative.org/documents/PDFFINALS/9Values.pdf

Landes, D. 2003. The Unbound Prometheus - Technological Change and Industrial Development in Western Europe from 1750 to the Present. $2^{\text {nd }}$ edition. Cambridge: Cambridge University Press.

Lebret, L-J. 1967. Développement $=$ Révolution Solidaire . Paris: Éditions Ouvrières.

Luttwak, E. 1999. Turbo-Capitalism: Winners and Losers in the Global Economy. New York: Harper Collins.

Lutz, M. 1992a. Humanistic economics: History and basic principles. In P. Ekins and M. Max-Neef (eds), Real Life Economics, 90-112. London: Routledge.

Lutz, M. 1992b. A humanistic approach to socio-economic development. In P. Ekins and M. Max-Neef (eds.), Real Life Economics, 165-7. London: Routledge,.

Lutz, M.A and K Lux. 1988. Humanistic Economics. New York: The Bootstrap Press.

Max-Neef, M., et al. 1989. Human-scale Development. Development Dialogue, 1989(1): 5-81.

Max-Neef, M. et al. 1991. Human Scale Development, New York: Apex Press and London: Zed Books.

Max-Neef, M. 1992. Development and Human Needs. In P. Ekins \& M. Max-Neef eds., Real-Life Economics, 197-213. London: Routledge.

McCann, C.R., ed. 2003. The Elgar Dictionary of Economic Quotations, Cheltenham: Edward Elgar.

McNeill, D., and A. L. St. Clair. 2009. Global Poverty, Ethics and Human Rights: The Role of Multilateral Organisations. London and New York: Routledge.

Mokyr, J. 2006 (reprint; first published 1983). Why Ireland Starved: A Quantitative and Analytical History of the Irish Economy 1800-1850. Taylor and Francis.

Murphy, C. 2006. The United Nations Development Programme: A Better Way? Cambridge: Cambridge University Press.

Narayan, D., R. Chambers, M.K Shah, and P. Petesch. 2000. Voices of the Poor: Crying Out for Change. New York: Oxford University Press.

Narayan, D., R. Patel, K. Schafft, and A. Rademacher. 2000. Voices of the Poor: Can Anyone Hear Us? New York: Oxford University Press

Narayan, D. and P. Petesch. 2002. Voices of the Poor from Many Lands. New York: Oxford University Press.

Oliver-Smith, A., 2009. Development and Dispossession. In Oliver-Smith (ed.), Development \& Dispossession: The Crisis of Forced Displacement and Resettlement, 3-23. Santa Fe, NM: SAR Press.

O’Neill, O., 1996. Towards Justice and Virtue. Cambridge: Cambridge University Press.

Penz, P. 2003. Development, displacement and international ethics. In P. Quarles van Ufford and A.K. Giri eds., A Moral Critique of Development, 139-152. London: Routledge.

Penz, P., J. Drydyk, P. Bose, 2011. Displacement by Development - Ethics, Rights and Responsibilities. Cambridge University Press.

Pick, S., \& J. Sirkin, 2010. Breaking the Poverty Cycle: The human basis for sustainable development. New York: Oxford University Press.

Polanyi, K. 1957. The Great Transformation. New York: Beacon Books.

Quataert, J.H. 2009. Advocating Dignity - Human Rights Mobilizations in Global Politics. Philadelphia: University of Pennsylvania Press.

Quarles van Ufford, P., \& A.K. Giri (eds.). 2003. A Moral Critique of Development. London: Routledge.

Qizilbash, M. 2002. Development, common foes and shared values, Review of Political Economy, 14(4).

Raskin, P. 2006. World Lines: Pathways, Pivots and the Global Future. http://www.gtinitiative.org/, Great Transition Initiative, Paper 16.

Raskin, P., T. Banuri, G. Gallopin, P. Gutman, A. Hammond, R. Kates, R. Swart, 2002. Great Transition. Boston, MA: Stockholm Environment Institute.

Schwenke, C. 2008. Reclaiming Value in International Development: The Moral Dimensions of Development Policy and Practice in Poor Countries. Portsmouth: Greenwood Press.

Scudder, T., 2005. The Future of Large Dams: Dealing with Social, Environmental, Institutional and Political Costs. London: Earthscan.

Sen, A.K. 1981. Poverty and Famines. Oxford: Clarendon Press. 
Sen, A.K. 1987. On Ethics and Economics. Oxford: Blackwell.

Sen, A.K. 2009. The Idea of Justice. London: Penguin.

St. Clair, A.L. 2007. A Methodologically Pragmatist Approach to Development Ethics. Global Ethics, 3(2): 141-162.

Stiglitz, J. 2005. Ethics, Economic Advice, and Economic Policy. Policy Innovation, journal of The Carnegie Council, New York.

http://www.policyinnovations.org/ideas/policy_library/data/01216/:pf_printable

Stiglitz, J. 2007. Making Globalization Work, expanded edition. New York: WW Norton.

Tawney, R.H. 1926. Religion and the Rise of Capitalism. London: John Murray.

UNDP. 2007. Human Development Report 2007/8 - Fighting Climate Change: Human solidarity in a divided world. New York: UNDP.

Wilber, C.K., and A.K. Dutt (eds.). 2010. New Directions In Development Ethics, Essays In Honor Of Denis Goulet. Notre Dame (IN): Univ. of Notre Dame Press.

World Commission on Dams. 2000. Dams and Development - A New Framework for Decision-Making. London: Earthscan, and www.dams.org. 